\title{
Effect of Feeding Different Levels of Moringa Leaf Powder on Immune Response in Raja II Broiler Chicken
}

\author{
K. Sudharshan ${ }^{1 *}$, H. C. Indresh ${ }^{1}$, T. N. Krishnamurthy ${ }^{2}$ and B. C. Umashankar ${ }^{3}$ \\ ${ }^{1}$ Department of Poultry Science, Veterinary College, Hebbal, Bengaluru, India \\ ${ }^{2}$ Department of Livestock Production and Management, Veterinary College, \\ Shivamogga, India \\ ${ }^{3}$ Department of Animal Nutrition, Veterinary College, Hebbal, Bengaluru, India \\ *Corresponding author
}

\section{A B S T R A C T}

\section{Keywords}

Immune response, Newcastle disease, Infectious bursal disease and Raja II broiler

\section{Article Info}

Received: 10 November 2021 Accepted:

05 December 2021 Available Online: 10 December 2021
An experiment was conducted to study the effect of feeding different levels of Moringa leaf powder on immunological response in Raja II broiler chicken. A total of 150 one day old Raja II broiler chicks were distributed into five treatment groups with three replicates in each group and ten chicks in each replicate. Basal diet (T1) prepared following Indian council of agricultural research (2013) standards and the experimental diets were prepared by incorporating moringa leaf powder at 2.5 per cent (T2), 5 per cent (T3), 7.5 per cent (T4) and 10 per cent (T5). Blood samples will be collected from two birds from each replicate on $42^{\text {nd }}$ day. Serum will be separated and antibody titer against Newcastle disease virus and Infectious bursal disease virus will be estimated by HI and ELISA test, respectively. At the end of the experiment, two birds from each replicate in each treatment groups will be slaughtered to record the weights of lymphoid organs viz., thymus, bursa fabricius and spleen. Results revealed no significant improvement on immune response against Newcastle disease and Infectious bursal disease on the $42^{\text {nd }}$ day of the experiment and also non-significant difference on immune organ weight.

\section{Introduction}

Chickens are important source of animal protein and can be raised in situations with limited feed resources (Olwande et al., 2010). In other hand poultry industry is highly dependent on feed cost which accounts the major cost of poultry production. The bulk of the feed cost arises from protein concentrates such as soybean Meal (SBM), groundnut cake and fish meal. Prices of these conventional protein sources have soared so high in recent times that it is becoming uneconomical to use them in poultry feeds. There is a need 
therefore, to look for locally available and cheap sources of feed ingredients. One possible source of cheap protein is the leaf meal of tropical legumes. Many studies have been conducted using various sources of leaf meal proteins for poultry (Iheukwumere et al., 2008; Wude and Berhan, 2009; Onyimonyi et al., 2009).

Leaf meals do not only serve as source of protein but also provides some necessary vitamins, minerals and oxycarotenoids (D’Mello et al., 1987; Opara, 1996). One plant that can serve as source of leaf meal in the diet of poultry is Moringa olifera tree (Kakengi et al., 2007; Olugbemi et al., 2010). Moringa oleifera has been claimed to boost immune systems (Fuglier, 1999), such property of the plant most likely might be contained and restricted to the pods and leaves which possesses lectin, a substance that modulates body defence system.

Allam et al., (2016) reported that Moringa leaf extract act as antibacterial growth promoter, antioxidant, claimed to boost immune systems and hemato-biochemical parameters in broilers. The average HI titre revealed non significant $(\mathrm{P}>0.05)$ differences among the experimental groups. The supplementation of moringa leaf powder in broiler diet could not exert significant changes in antibody titre against Ranikhet disease in broilers.

El-Deep et al., (2019) found that mRNA expression of IL2 and IL6 significantly increased at 5 per cent Moringa oleifera leaf meal inclusion in broilers under normal and heat stress condition. The cell-mediated immune response to phytohaemagglutinin phosphate was not influenced, but the antibody titre and humoral immune response against Newcastle disease (ND) vaccine was significantly $(\mathrm{P}<0.05)$ improved and reduced the lipid peroxidation in the liver of commercial broilers by supplementation of
MOLM up to $1000 \mathrm{mg} / \mathrm{kg}$ of diet in broiler diet at 42 days of age (Rao et al., 2019).

Sugiharto et al., (2020) studied the effect of feeding fermented mixture of cassava pulp and Moringa oleifera leaf meal on immune responses and antioxidative status and revealed that higher serum superoxide dismutase activity, lower malondialdehyde biomarker and better haematological values in the group fed with fermented mixture of cassava pulp and Moringa oleifera leaf meal than control indicates better antioxidative status of broilers.

\section{Materials and Methods}

A total of one hundred and fifty, day-old Raja II broiler chicks were procured from the Department of Poultry Science, Veterinary College, Hebbal, Bengaluru. All the chicks were weighed and wing banded individually. The chicks were allocated to five different treatment groups each consisting of three replicates with 10 chicks each (30 chicks per treatment). Each of the treatment groups fed with different types of experimental diets. The control group $\mathrm{T}_{1}$ fed with basal diet as per Indian council of agricultural research (2013) standards. The treatment groups $\mathrm{T}_{2}, \mathrm{~T}_{3}, \mathrm{~T}_{4}$ and $\mathrm{T}_{5}$ fed with basal diet containing different levels $\left(\mathrm{T}_{2,-}-2.5 \%, \mathrm{~T}_{3}-5 \%, \mathrm{~T}_{4}-7.5 \%\right.$ and $\mathrm{T}_{5}$ $-10 \%$ ) of Moringa leaves powder. The chicks were reared in deep litter system and maintained under standard managemental practices till 6 weeks of age. Standard vaccination schedule followed for immunizing the birds. Birds were fed with diets as per the ICAR (2013) specifications. Feed and water provided ad libitum throughout the experimental period.Blood samples will be collected from two birds from each replicate on $42^{\text {nd }}$ day. Serum will be separated and antibody titer against new castle disease virus and infectious bursal disease virus will be estimated by HI and ELISA test, respectively. 
At the end of the experiment, two birds from each replicate in each treatment groups will be slaughtered to record the weights of lymphoid organs viz., thymus, bursa fabricius and spleen.

\section{Results and Discussion}

The results of the effect of feeding different levels of Moringa leaf powder on antibody titers against Newcastle disease and Infectious bursal disease during $42^{\text {nd }}$ day in Raja II broiler chicken were presented in Table 1 and lymphoid organ weights in Table 2. There was no significant difference $(\mathrm{P}>0.05)$ on lymphoid organ weight and immunological response against Newcastle disease and Infectious bursal disease of birds in the groups fed with Moringa leaf powder compared to the control group at the end of the experiment $\left(6^{\text {th }}\right.$ week).

At the end of $42^{\text {nd }}$ day, the antibody titers against Newcastle disease in groups $\mathrm{T}_{1}, \mathrm{~T}_{2}, \mathrm{~T}_{3}$, $\mathrm{T}_{4}$ and $\mathrm{T}_{5}$ were 1.361, 1.386, 1.407, 1.404 and 1.391 and the antibody titers against Infectious bursal disease were 2560.34, 2431.65, 2489.78, 2514.56 and 2526.17, respectively.

The weight of thymus (\%) on $42^{\text {nd }}$ day of the experiment in groups $\mathrm{T}_{1}, \mathrm{~T}_{2}, \mathrm{~T}_{3}, \mathrm{~T}_{4}$ and $\mathrm{T}_{5}$ were $0.306,0.317,0.324,0.312$ and 0.320 ; weight of bursa of fabricus (\%) were 0.132 , $0.138,0.133,0.139$ and 0.141 and weight of spleen $(\%)$ were $0.164,0.181,0.174,0.186$ and 0.180 , respectively.

In similar to the present study Eze et al., (2013) who studied immune boosting potential of crude methanolic extract of Moringa oleifera in broilers experimentally challenged with Newcastle disease (ND) virus reported increases in total and differential cell numbers and haemagglutination inhibition (HI) titre in the extracts of Moringa oleifera treated groups did not correlate with total protection against ND. The present study is in agreement with (Laxman et al., 2016) who conducted the experiment in which the average $\mathrm{HI}$ titre revealed non-significant $(\mathrm{P}>0.05)$ differences among the experimental groups. The supplementation of moringa leaf powder in broiler diet could not exert significant changes in antibody titre against Ranikhet disease in broilers.

The results of present study are similar with Allam et al., (2016) who reported that Moringa leaf extract act as antibacterial growth promoter, antioxidant, claimed to boost immune systems and hematobiochemical parameters in broilers.

The average $\mathrm{HI}$ titre revealed non significant $(\mathrm{P}>0.05)$ differences among the experimental groups. The supplementation of moringa leaf powder in broiler diet could not exert significant changes in antibody titre against Ranikhet disease in broilers.

The present study is in agreement with Laxman (2016) who conducted the experiment, in which immune organs revealed non-significant $(\mathrm{P}>0.05)$ differences among the experimental groups. In similar to the present study Eze et al., (2013) conducted the experiment, in which immune organs revealed non-significant difference among the experimental groups when compared to the control group.

The present study is in contrary with Didacus et al., (2013) who observed that Moringa oleifera extract increased ND HI titre and the total and differential leukocyte counts in MOLM treated and unvaccinated group I much more than those of MOLM treated and vaccinated group II, hence it could be recommended as a prophylactic treatment against ND in non-vaccinated birds. 
Table.1 Effect of feeding different levels of Moringa oleifera leaf powder on antibody titers against Newcastle disease ( $\log _{10} \mathrm{HI}$ titer) and Infectious bursal disease (ELISA) on $42^{\text {nd }}$ day in Raja II broiler birds.

\begin{tabular}{|c|c|c|c|}
\hline Experimental group & Description of the treatment & NDV & IBDV titer \\
\hline T1 & Basal Diet & $1.361 \pm 0.168$ & $2560.34 \pm 277.40$ \\
\hline $\mathbf{T 2}$ & $\begin{array}{l}2.5 \% \text { Moringa oleifera leaves } \\
\text { powder in basal diet }\end{array}$ & $1.386 \pm 0.154$ & $2431.65 \pm 281.94$ \\
\hline T3 & $\begin{array}{c}5 \% \text { Moringa oleifera leaves } \\
\text { powder in basal diet }\end{array}$ & $1.407 \pm 0.093$ & $2489.78 \pm 213.06$ \\
\hline T4 & $\begin{array}{l}7.5 \% \text { Moringa oleifera leaves } \\
\text { powder in basal diet }\end{array}$ & $1.404 \pm 0.139$ & $2514.56 \pm 369.71$ \\
\hline T5 & $\begin{array}{l}10 \% \text { Moringa oleifera leaves } \\
\text { powder in basal diet }\end{array}$ & $1.391 \pm 0.176$ & $2526.17 \pm 163.80$ \\
\hline
\end{tabular}

Table.2 Effect of feeding different levels of Moringa oleifera leaf powder on Lymphoid organs weight (\% live weight) (Mean \pm SE) in Raja II broiler birds

\begin{tabular}{|c|c|c|c|c|}
\hline Experimental group & Description of the treatment & \multicolumn{3}{|c|}{ Lymphoid organs weight (g/100g body weight) } \\
\cline { 5 - 5 } & THYMUS & BURSA & SPLEEN \\
\hline T1 & Basal Diet & $0.306 \pm 0.017$ & $0.132 \pm 0.015$ & $0.164 \pm 0.037$ \\
\hline T2 & $\begin{array}{c}\mathbf{2 . 5} \% \text { Moringa oleifera } \\
\text { leaves powder in basal diet }\end{array}$ & $0.317 \pm 0.023$ & $0.138 \pm 0.033$ & $0.181 \pm 0.021$ \\
\hline T3 & $\begin{array}{c}\mathbf{5} \% \text { Moringa oleifera leaves } \\
\text { powder in basal diet }\end{array}$ & $0.324 \pm 0.012$ & $0.133 \pm 0.010$ & $0.174 \pm 0.024$ \\
\hline T4 & $\begin{array}{c}\mathbf{7 . 5 \%} \text { Moringa oleifera } \\
\text { leaves powder in basal diet }\end{array}$ & $0.312 \pm 0.028$ & $0.139 \pm 0.012$ & $0.186 \pm 0.012$ \\
\hline T5 & $\begin{array}{c}\mathbf{1 0} \% \text { Moringa oleifera } \\
\text { leaves powder in basal diet }\end{array}$ & $0.320 \pm 0.022$ & $0.141 \pm 0.010$ & $0.180 \pm 0.015$ \\
\hline
\end{tabular}

The findings of present study are disagreement with Rao et al., (2019) who observed cellmediated immune response to phytohaemagglutinin phosphate was not influenced, but the antibody titre and humoral immune response against Newcastle disease (ND) vaccine was significantly $(\mathrm{P}<0.05)$ improved and reduced the lipid peroxidation in the liver of commercial broilers by supplementation of MOLM up to $1000 \mathrm{mg} / \mathrm{kg}$ of diet in broiler diet at 42 days of age. Based on the above results inclusion of different levels of moringa leaf powder in basal diet had no significant improvement on immune response against Newcastle disease and Infectious bursal disease on the $42^{\text {nd }}$ day of the experiment and also showed non-significant $(\mathrm{P}>0.05)$ difference on immune organs weight of birds fed with different treatment groups compared to control at the end of the experiment $\left(42^{\text {nd }}\right.$ day).

\section{References}

Allam, H., A. M. Abdelazem., H. S. Farag. and A. Hamed., 2016. Some hemato-biochemical, bacteriological and pathological effects of Moringa oleifera leaf extract in broiler chickens. Int. J. Basic Applied Sci., 5: 99-104

D'Mello, J., Acamovic, T. and Walker, A. G., 1987. Evaluation of leucaena leaf meal for 
broiler growth and pigmentation. Trop. Agric. (Trinidad), 64: 33-35

Didacus. C. E Z E., Okwor, E. C., Okoye, J. O. and Onah, D. N., 2013. Immunologic effects of Moringa oleifera methanolic leaf extract in chickens infected with Newcastle disease virus (kudu 113) strain. Afr. $J$. Pharm.Pharmacol., 7(31): 2231-2237

El Deep, M. H., Dawood, M. A. O., Assar, M. H. and Ijiri D, O. A., 2019. Dietary Moringa oleifera improves growth performance, oxidative status, and immune related gene expression in broilers under normal and high temperature conditions. J. Therm. Biol. 82: $157-163$

Eze, D. C., Okwor, E. C., Okoye, J. O. and Onah, D. N., 2013. Immunologic effects of Moringa oleifera methanolic leaf extract in chickens infected with Newcastle disease virus (kudu 113) strain. Afr. J. Pharm.Pharmacol., 7(31): 2231-2237

Fuglier, L., 1999. The Miracle Tree: Moringa oleifera, Natural Nutrition for the Tropics. Church World Service, Dakkar, Senegal.

Iheukwumere, F. C., E. C. Ndubuisi, E. A. Mazi and M. U. Onyekwere, 2008. Performance, nutrient utilization and organ characteristics of broilers fed cassava leaf meal (Manihot esculenta Crantz). Pak. J. Nutr., 7: 13-16

Kakengi, A., J. Kaijage, S. Sarwatt, S. Mutayoba, M. Shem and T. Fujihara, 2007. Effect of Moringa oleifera leaf meal as a substitute for sunflower seed meal on performance of laying hens in Tanzania. Livest. Res. Rural Dev., 19

Laxman, A. J., 2016. Effect of supplementation of Moringa oleifera leaf powder on performance of broilers. M.Sc. Thesis, University of Maharashtra Animal and Fishery Science, Nagpur, India

Olugbemi, T. S., S. K. Mutayoba and F. P. Lekule,
2010. Moringa oleifera leaf meal as a hypocholesterolemic agent in laying hen diets. Livest. Res. Rural Dev., 22

Olwande, P. O., Ogara, W. O., Okuthe, S. O., Muchemi, G., Okoth, E., Odindo, M. O. and Adhiambo, R. F., 2010. Assessing the productivity of indigenous chickens in an extensive management system in southern Nyanza. Kenya. Trop. Anim. Health Prod., 42: 283-288

Onyimonyi, A. E., O. Adeyemi and G. C. Okeke, 2009. Performance and economic characteristics of broilers fed varying dietary levels of neem leaf meal (Azadirachta indica). Int. J. Poult. Sci., 8: 256-259

Opara, C. C., 1996. Studies on the Use of Aklchornia cordifolla Leaf Meal as Feed Ingredient in Poultry Diets. MSc Thesis. Federal University of Technology, Owerri, Nigeria.

Rao, S. R., Raju, M. V. L. N., Prakash, B., Rajkumar, U. and Reddy, E. P. K., 2018. Effect of supplementing moringa (Moringa oleifera) leaf meal and pomegranate (Punica granatum) peel meal on performance, carcass attributes, immune and antioxidant responses in broiler chickens. Anim. Prod. Sci., 59(2): 288-294

Sugiharto, S., Yudiarti, T., Isroli, I., Widiastuti, E., Wahyuni, H. I. and Sartono, T. A., 2020.Feeding Fermented Mixture of Cassava Pulp and Moringa oleifera Leaf Meal: Effect on Growth, Internal Organ and Carcass of Broiler Chickens. Agric. Conspectus Sci., 85(1): 87-93

Wude, T. and T. Berhan, 2009. The effect of increasing levels of dried leaves of sweet potato (Ipomoea batatas) on dry matter intake and body weight gain performance of broiler finisher chicks. Livest. Res. Rural Dev., 21.

\section{How to cite this article:}

Sudharshan, K., H. C. Indresh, T. N. Krishnamurthy and Umashankar, B. C. 2021. Effect of Feeding Different Levels of Moringa Leaf Powder on Immune Response in Raja II Broiler Chicken. Int.J.Curr.Microbiol.App.Sci. 10(12): 478-482. doi: https://doi.org/10.20546/ijcmas.2021.1012.053 